\title{
Increased lignocellulosic inhibitor tolerance of Saccharomyces cerevisiae cell populations in early stationary phase
}

Venkatachalam Narayanan, Jenny Schelin, Marie Gorwa-Grauslund, Ed WJ van Niel and Magnus Carlquist ${ }^{*}$

\begin{abstract}
Background: Production of second-generation bioethanol and other bulk chemicals by yeast fermentation requires cells that tolerate inhibitory lignocellulosic compounds at low pH. Saccharomyces cerevisiae displays high plasticity with regard to inhibitor tolerance, and adaptation of cell populations to process conditions is essential for reaching efficient and robust fermentations.

Results: In this study, we assessed responses of isogenic yeast cell populations in different physiological states to combinations of acetic acid, vanillin and furfural at low pH. We found that cells in early stationary phase (ESP) exhibited significantly increased tolerance compared to cells in logarithmic phase, and had a similar ability to initiate growth in the presence of inhibitors as pre-adapted cells. The ESP cultures consisted of subpopulations with different buoyant cell densities which were isolated with flotation and analysed separately. These so-called quiescent (Q) and non-quiescent (NQ) cells were found to possess similar abilities to initiate growth in the presence of lignocellulosic inhibitors at pH 3.7, and had similar viabilities under static conditions. Therefore, differentiation into Q-cells was not the cause for increased tolerance of ESP cultures. Flow cytometry analysis of cell viability, intracellular pH and reactive oxygen species levels revealed that tolerant cell populations had a characteristic response upon inhibitor perturbations. Growth in the presence of a combination of inhibitors at low pH correlated with pre-cultures having a high frequency of cells with low $\mathrm{pH}_{i}$ and low ROS levels. Furthermore, only a subpopulation of ESP cultures was able to tolerate lignocellulosic inhibitors at low pH, while pre-adapted cell populations displayed an almost uniform high tolerance to the adverse condition. This was in stark contrast to cell populations growing exponentially in non-inhibitory medium that were uniformly sensitive to the inhibitors at low $\mathrm{pH}$.

Conclusions: ESP cultures of S. cerevisiae were found to have high tolerance to lignocellulosic inhibitors at low pH, and were able to initiate growth to the same degree as cells that were pre-adapted to inhibitors at a slightly acidic pH. Carbon starvation may thus be a potential strategy to prepare cell populations for adjacent stressful environments which may be beneficial from a process perspective for fermentation of non-detoxified lignocellulosic substrates at low $\mathrm{pH}$. Furthermore, flow cytometry analysis of $\mathrm{pH}_{\mathrm{i}}$ and $\mathrm{ROS}$ level distributions in ESP cultures revealed responses that were characteristic for populations with high tolerance to lignocellulosic inhibitors. Measurement of population distribution responses as described herein may be applied to predict the outcome of environmental perturbations and thus can function as feedback for process control of yeast fitness during lignocellulosic fermentation.
\end{abstract}

Keywords: Carbon starvation, Stress tolerance, Acetic acid, Vanillin, Furfural, Reactive oxygen species, Intracellular pH, Quiescence, Population heterogeneity

*Correspondence: magnus.carlquist@tmb.lth.se

Division of Applied Microbiology, Department of Chemistry, Lund

University, P.O. Box 124, SE 22100 Lund, Sweden 


\section{Background}

Adverse impacts of climatic change and concerns over energy security could be abated by replacing petrochemicals with chemicals produced from lignocellulose, which is the most abundant renewable feedstock on the planet and is available from industrial and agricultural residues. Intense research and development for decades have led to the onset of commercial scale production of lignocellulosic bioethanol using the industrial workhorse Saccharomyces cerevisiae. Although many improvements could be done in biomass pretreatment [1,2], enzymatic hydrolysis [3] and inhibitor detoxification [4], the robustness of S. cerevisiae towards adverse process conditions is still a key engineering target to increase productivity, avoid loss of fermentable sugars and therefore reduce production costs [5]. An important hurdle to overcome for maintaining high cell activity is the negative effect of lignocellulosic inhibitors produced by the most common pretreatment methods; these include furaldehydes such as furfural and hydroxymethylfurfural (HMF), phenolics such as vanillin and 4-hydroxybenzoic acid and weak organic acids such as acetic acid, formic acid and levulinic acid (see reviews [5-7]).

Cell tolerance to lignocellulosic inhibitors is a highly plastic phenotype and depends on the environment that the cell population has experienced before exposure. For example, pre-cultivation in lignocellulosic hydrolysate containing furfural and HMF leads to induced expression of genes coding for specific NADPH-dependent oxidoreductases, e.g. Adh6 [8], that reduce the aldehyde moiety into less inhibitory furfuryl alcohols resulting in a shortened latency phase in the fermentation [9]. Tolerance to vanillin is similarly correlated to increased reduction to the less toxic vanillyl alcohol [10]. Also the tolerance to acetic acid at low $\mathrm{pH}$ is increased by pre-cultivation in medium supplemented with acetic acid at slightly acidic $\mathrm{pH}$ [11]. The acid tolerance is partly caused by an induced expression of the $H A A 1$ gene coding for a global transcription factor that activates multiple genes, including TPO1 and TPO2 coding for drug/ $\mathrm{H}+$-antiporters which export dissociated acetate from the cytoplasm [12, 13]. For these reasons, improved fermentation of lignocellulosic substrates can be reached through adapting cell populations by pre-exposure to moderate inhibitor levels in the pre-cultivation step $[14,15]$.

The level of cellular resistance to a specific stress is determined both by stress-specific and general mechanisms. For example, it was previously found that a slow growth rate correlates with increased tolerance towards a number of seemingly non-related stresses [16]. The extreme case are cells in stationary phase (SP), which are characterized by increased cell robustness to heat shock, osmotic stress, freeze-thaw stress and weak acid stress [17-21]. The higher robustness of SP-cells is often explained by activation of multiple cellular regulatory events upon nutrient starvation, including the environmental stress response (ESR), which leads to adjustment of cellular resources to promote survival in adjacent environments (see reviews [22, 23]). Based on this, it can be proposed that increased tolerance to lignocellulosic conditions may be reached without pre-exposure to inhibitors, for example, by allowing cells to reach SP by carbon starvation prior to the fermentation step.

The aim of the current study was to investigate correlations between the physiological state of yeast populations and their aptitude to tolerate combinations of lignocellulosic inhibitors (vanillin, furfuraldehyde and acetic acid) at low $\mathrm{pH}$. In particular, physiological responses of cells in SP, including the previously described quiescent $(\mathrm{Q})$ and non-quiescent (NQ) cells [24-26], were investigated in detail. Furthermore, flow cytometry (FCM) measurements of cell viability, the intracellular $\mathrm{pH}\left(\mathrm{pH}_{\mathrm{i}}\right)$ and reactive oxygen species (ROS) levels were applied to compare the responses of cell populations in early stationary phase (ESP) to those of cells in logarithmic phase (LP), and cells pre-adapted to lignocellulosic inhibitors.

\section{Methods}

\section{Strains and media}

Saccharomyces cerevisiae strains used in this study are listed in Table 1 . They were stored at $-80^{\circ} \mathrm{C}$ in Yeast Peptone (YP) medium containing $10 \mathrm{~g} \mathrm{~L}^{-1}$ yeast extract, $20 \mathrm{~g}$ $\mathrm{L}^{-1}$ peptone and $20 \mathrm{~g} \mathrm{~L}^{-1}$ glucose supplemented with $30 \%(\mathrm{v} / \mathrm{v})$ glycerol and maintained on YP agar plates containing $10 \mathrm{~g} \mathrm{~L}^{-1}$ yeast extract, $20 \mathrm{~g} \mathrm{~L}^{-1}$ peptone, $20 \mathrm{~g} \mathrm{~L}^{-1}$ glucose and $15 \mathrm{~g} \mathrm{~L}^{-1}$ agar. A chemically defined medium

Table 1 S. cerevisiae strains used in this study

\begin{tabular}{lll}
\hline Strain & Genotype & Source \\
\hline CEN.PK 113-7D & MATa MAL2-8c SUC2 & EUROSCARF, Frankfurt, Germany \\
CEN.PK 113-5D & MATa MAL2-8c SUC2 ura3 & EUROSCARF, Frankfurt, Germany \\
TMB3800 & CEN.PK 113-5D; pYES-P $P_{A C T 1}$-pHlourin (URA3) & This study \\
TMB3500 & Wild brewer's strain & {$[15]$} \\
\hline
\end{tabular}


[27] with $20 \mathrm{~g} \mathrm{~L}^{-1}$ glucose, buffered to $\mathrm{pH} 3.7,5.0$ or 6.5 with $50 \mathrm{mM}$ potassium hydrogen phthalate [28] and supplemented with or without $6 \mathrm{~g} \mathrm{~L}^{-1}$ acetic acid, $0.75 \mathrm{~g}$ $\mathrm{L}^{-1}$ furfural and $0.2 \mathrm{~g} \mathrm{~L}^{-1}$ vanillin was used in all aerobic growth experiments. Vitamins, trace elements, furfural and vanillin were filter-sterilized to avoid changes in composition due to evaporation during autoclavation. Escherichia coli strain NEB5 $\alpha$ (New England Biolabs) was recovered from $25 \%$ glycerol stock stored at $-80{ }^{\circ} \mathrm{C}$ and used for subcloning of plasmid DNA and further propagation. Luria-Bertani broth (LB) $\left(5 \mathrm{~g} \mathrm{~L}^{-1}\right.$ yeast extract, $10 \mathrm{~g} \mathrm{~L}^{-1}$ tryptone and $5 \mathrm{~g} \mathrm{~L}^{-1} \mathrm{NaCl}, \mathrm{pH}$ 7.5) medium was used for culturing $E$. coli and $50 \mathrm{mg} \mathrm{L}^{-1}$ ampicillin was added to the LB medium when required. Media components were purchased from Sigma-Aldrich (Sweden), unless mentioned otherwise.

\section{Construction of $S$. cerevisiae strain expressing pHluorin}

Competent $E$. coli NEB5 $\alpha$ cells were prepared using the $\mathrm{RbCl}$ method described in the subcloning notebook from Promega, which is adapted from the method described by [29]. The competent cells were transformed according to the supplier's instructions (New England Biolabs). Bacterial transformants were selected on solid LB plates (15 $\mathrm{g} \mathrm{L}^{-1}$ agar), supplemented with ampicillin (50 mg $\mathrm{L}^{-1}$ ), for $16 \mathrm{~h}$ at $37^{\circ} \mathrm{C}$. Plasmid preparation from E. coli transformants was performed using GeneJet ${ }^{\mathrm{TM}}$ Plasmid Miniprep kit (Thermo Scientific, Waltham, USA). S. cerevisiae CEN.PK 113-5D was grown in liquid YPD medium for $14-16 \mathrm{~h}$ at $30^{\circ} \mathrm{C}$ and $180 \mathrm{rpm}$ in a rotary shake incubator (New Brunswick, Enfield, CT, USA) when preparing the strain for transformation. It was transformed with the URA3-based $2 \mu$ episomal plasmid pYES-pACT1pHluorin [30] using the high-efficiency LiAc method [31], and the engineered yeast strain (henceforth mentioned as TMB3800) was selected on YNB-glucose plates (6.7 $\mathrm{g} \mathrm{L}^{-1}$ Yeast Nitrogen Base without amino acids (Becton, Dickinson and Company, USA) supplemented with $20 \mathrm{~g} \mathrm{~L}^{-1}$ glucose and $15 \mathrm{~g} \mathrm{~L}^{-1}$ agar).

\section{Aerobic batch cultivation in shake flasks}

Cultures were grown in a rotary shake incubator at $180 \mathrm{rpm}$ at $30{ }^{\circ} \mathrm{C}$ and cell concentrations were determined by optical density (OD) at $620 \mathrm{~nm}$ (Spectrophotometer U-1800, Hitachi, Berkshire, UK). Seed cultures were cultivated from single colonies of $S$. cerevisiae strains (from solid media) in $5 \mathrm{~mL}$ defined medium at $\mathrm{pH}$ 6.5 in a $50-\mathrm{mL}$ conical tube until late exponential phase. Cells from the seed culture were harvested by centrifugation at $3056 \mathrm{~g}$ for $5 \mathrm{~min}$ at $4{ }^{\circ} \mathrm{C}$ (Eppendorf centrifuge $5810 \mathrm{R}$, USA), washed with saline solution $(0.9 \% \mathrm{NaCl})$ and subsequently used for inoculation of the pre-culture at an initial $\mathrm{OD}_{620}$ of 0.5. Cells from the pre-culture were harvested at different phases of cultivation and used to inoculate the final cultivation. Pre-cultivation and subsequent cultivations were performed in baffled shake flasks with the medium volume equivalent to $10 \%$ of baffled shake volume to maintain adequate aeration. All the experiments were carried out in biological replicates $(n=2$ or 3$)$ and measurements were carried out in technical triplicate.

\section{Flotation}

TMB3500 was grown for $24 \mathrm{~h}$ until ESP, subsequently Q- and NQ-cells were separated by flotation [32]. For the flotation procedure, three different sterile colloidal solutions of non-toxic silanized silica particles in $0.9 \%$ $\mathrm{NaCl}$, all formulated by QRAB (Alunda, Sweden) and produced by FertiPro N.V., Beernem, Belgium were used. The densities of the solutions were adjusted to previously reported buoyant cell densities for Q- $\left(1.14 \mathrm{~g} \mathrm{~mL}^{-1}\right)$ and NQ-cells $\left(1.10 \mathrm{~g} \mathrm{~mL}^{-1}\right)$ [24] as follows: BactXtractorL (BX-L; density, $1.06 \mathrm{~g} \mathrm{~mL}^{-1}$ ), BactXtractor-M (BX$\mathrm{M}$; density, $1.12 \mathrm{~g} \mathrm{~mL}^{-1}$ ) and BactXtractor-H (BX-H; density, $1.29 \mathrm{~g} \mathrm{~mL}^{-1}$ ). The final densities of BX-L and BX-M were reached after dilution of BX-H with sterile $0.9 \% \mathrm{NaCl}$ and measured using a DMA46 density metre (Instrument AB Lambda, Stockholm, Sweden). The flotation media were stored at $4{ }^{\circ} \mathrm{C}$. Initially cells from an ESP culture of TMB3500 were harvested by centrifugation and homogenously re-suspended in $3 \mathrm{~mL} \mathrm{BX}-\mathrm{H}$ in a 15-mL Falcon Tube (Sarstedt, Nümbrecht, Germany). A discontinuous gradient was then created by the careful addition of $6 \mathrm{~mL}$ of BX-M followed by $2 \mathrm{~mL}$ of BX-L. The tube was centrifuged at $3056 \mathrm{~g}$ for $60 \mathrm{~min}$ at $4{ }^{\circ} \mathrm{C}$ using a swing-out centrifuge (Sigma 4-15C, Qiagen, Sweden) to separate Q- and NQ-cells. The two resulting cell fractions, due to differences in buoyant densities (Q-cells at the lower interphase between BX-H and BX-M layers, $\delta>1.12$; NQ-cells at the upper interphase between BX-M and BX-L layers, $\delta>1.06$ ), were collected using a syringe and needle. Each cell fraction was subsequently washed with sterile $0.9 \% \mathrm{NaCl}$ and centrifuged at $3056 g$ for $5 \mathrm{~min}$ at $4{ }^{\circ} \mathrm{C}$. Cells from each fraction were visualized in the microscope (Nikon optiphot with Zeiss axiscam MRm, Sweden) and were characterized further in subsequent growth analyses.

\section{Analysis of responses of unsorted ESP-, Q- and NQ-cells to lignocellulosic inhibitors}

TMB3500 was pre-cultured for $24 \mathrm{~h}$ to reach ESP and cells were harvested by centrifugation at $3056 \mathrm{~g}$ for 5 min at $4{ }^{\circ} \mathrm{C}$. Unsorted ESP-cells, Q-cells and NQ-cells were inoculated at an $\mathrm{OD}_{620}$ of 0.5 in $200 \mu \mathrm{L}$ of 15 different media (Table 2) with varied concentrations of inhibitors (furfural, vanillin, acetic acid) at $\mathrm{pH} 3.7$ in 
Table 2 Inhibitor compositions of the media as defined by circumscribed central composite design

\begin{tabular}{llll}
\hline Media & Acetic acid $\left(\mathbf{g ~ L}^{-\mathbf{1}}\right)$ & Furfural $\left(\mathbf{g ~ L}^{-\mathbf{1}}\right)$ & Vanillin $\left(\mathbf{g ~ L}^{\mathbf{- 1}}\right)$ \\
\hline 1 & 1.00 & 0.50 & 0.50 \\
2 & 1.00 & 0.50 & 1.50 \\
3 & 1.00 & 1.50 & 0.50 \\
4 & 1.00 & 1.50 & 1.50 \\
5 & 6.00 & 0.50 & 0.50 \\
6 & 6.00 & 0.50 & 1.50 \\
7 & 6.00 & 1.50 & 0.50 \\
8 & 6.00 & 1.50 & 1.50 \\
9 & 0.00 & 1.00 & 1.00 \\
10 & 7.70 & 1.00 & 1.00 \\
11 & 3.50 & 0.16 & 1.00 \\
12 & 3.50 & 1.84 & 1.00 \\
13 & 3.50 & 1.00 & 0.16 \\
14 & 3.50 & 1.00 & 1.84 \\
$15^{\mathrm{a}}$ & 3.50 & 1.00 & 1.00 \\
\hline
\end{tabular}

a Medium 15 was used for 9 technical replicates

96-well microtiter plates covered with a transparent plastic film (Breathe easy, Diversified biotech, USA) to prevent evaporation. Concentrations of the inhibitors were defined with a circumscribed central composite design equation (ccdesign) using Matlab (Release R2015a, The MathWorks, Inc., Natick, MA, USA). Growth was followed for $40 \mathrm{~h}$ by measuring $\mathrm{OD}_{620}$ with a multiscan ascent spectrophotometer (ThermoFisher Scientific, Sweden). Three-way ANOVAs (anovan) using Matlab were performed to see any effect of individual inhibitors on growth after $14 \mathrm{~h}$ with the different inocula (Unsorted ESP-, Q- and NQ-cells) (Additional file 1: Tables S1-3). A principle component analysis (PCA) of the whole dataset with ESP-, Q- and NQ-cells as loads and medium (M115) as scores was performed using the $p c a$ function in Matlab. Lag times and maximum specific growth rates were calculated by fitting the raw data to the modified Gompertz growth equation [33] using the Solver function to minimize sum of least squares in Excel (Microsoft, 2013, USA).

\section{Flow cytometry analysis}

A BD Accuri ${ }^{\text {TM }}$ C6 flow cytometer equipped with a Csampler (Becton-Dickinson, NJ, USA) was used to measure viability [34] and ROS [35], as described previously. Quality control of the instrument was made with 6 and 8 peak fluorescent calibration beads. The fluidics was set to medium flow rate $\left(35 \mu \mathrm{L} \mathrm{s}{ }^{-1}\right)$, the threshold was set to 50,000 on the forward scatter channel, and 20,000 or 100,000 cells were collected at a rate between 3000 and 6000 events $\mathrm{s}^{-1}$. For determination of cell viability,
$1 \times 10^{7}$ cells $\mathrm{mL}^{-1}$ in phosphate-buffered saline solution (PBS) $\left(8 \mathrm{~g} \mathrm{~L}^{-1} \mathrm{NaCl}, 0.2 \mathrm{~g} \mathrm{~L}^{-1} \mathrm{KCl}, 1.42 \mathrm{~g} \mathrm{~L}^{-1} \mathrm{Na}_{2} \mathrm{HPO}_{4}\right.$ and $0.24 \mathrm{~g} \mathrm{~L}^{-1} \mathrm{KH}_{2} \mathrm{PO}_{4}, \mathrm{pH}$ 7.4) were stained with propidium iodide (PI) $\left(1 \mu \mathrm{g} \mathrm{mL}{ }^{-1}\right)$ and incubated in the dark for $10 \mathrm{~min}$. A blue laser $(488 \mathrm{~nm})$ was used for the excitation, and PI emission was collected at 585/40 nm. For determination of ROS, $1 \times 10^{6}$ cells mL $\mathrm{mL}^{-1}$ in PBS solution were stained with dihydroethidium (DHE) $\left(50 \mu \mathrm{g} \mathrm{mL}{ }^{-1}\right)$ and incubated in the dark for $20 \mathrm{~min}$. DHE permeates into cells and gets oxidized to ethidium when exposed to superoxide in a dose-dependent manner. Ethidium then intercalates with DNA and emits red fluorescence proportional to intracellular ROS $[35,36]$. A blue laser $(488 \mathrm{~nm})$ was used for the excitation, and DHE emission was collected at 585/40 nm. Cells in logarithmic phase grown in defined medium were used as live control and cells treated with $70 \%$ ethanol for 20 min were used as positive control for analysis of both viability and ROS. Autofluorescence was measured for unstained exponentially growing cells (CEN.PK 113-7D).

A Moflo XPD cell sorter (Becton-Dickinson, NJ, USA) with physically separated laser lines was used for ratiometric flow cytometry analysis of pHluorin fluorescence, as described previously [37]. Calibration of the instrument was made with fluorescent calibration beads (SPHERO Ultra rainbow fluorescent particles, $3.01 \mu \mathrm{M}$, Spherotech, USA). The threshold was set based on forward scatter obtained from blue laser $(488 \mathrm{~nm})$, and 100,000 cells were collected at a rate of approximately 5000 events/s. Excitation of pHluorin was made with a blue laser $(488 \mathrm{~nm})$ and a violet laser $(405 \mathrm{~nm})$, and the corresponding fluorescence emissions were collected with bandpass filters at 529/28 nm and 542/50 nm. The $\mathrm{pH}$ dependence of pHluorin was confirmed by measuring the ratio of fluorescence from the different excitation wavelengths, R405/488, in permeabilized cells in sodium phosphate buffer $(0.2 \mathrm{M})$ at different $\mathrm{pH}$ ranging from 5.7 to 8 . Permeabilization was made by incubating cells in PBS buffer ( $50 \mathrm{mM}, \mathrm{pH} 6.5)$ supplemented with digitonin (0.04 $\mathrm{mM}$ ) for $15 \mathrm{~min}$ at room temperature on a turning table, as described previously [30].

Flow cytometry standard (FCS) data files were exported from the BD Accuri C6 software (BD Biosciences, USA) or saved directly from the Kaluza software (Beckman coulter, USA) and analysed with FlowJo v10.1 (FlowJo, LLC Ashland, OR, USA). For determination of percent viable cells, the gate was defined based on PI fluorescence $(585 / 40 \mathrm{~nm})$ of live and dead cell controls samples. The live control sample was exponentially growing cells in defined mineral medium, and the dead control was prepared by incubating cells in $70 \%$ ethanol for at least $30 \mathrm{~min}$. An initial noise signal reduction was made for all samples by gating single cells based on the height and 
area of the forward scatter signal. pHluorin population was gated from autofluorescence (measured with a CEN. PK 113-7D strain without expression of pHluorin) using a bivariate plot of emissions at 542/50 nm and 529/28 nm, and excitation with the violet laser $(405 \mathrm{~nm})$ and the blue laser $(488 \mathrm{~nm})$, respectively. The pHluorin excitation ratio, R (F405/F488), for each cell was subsequently calculated using the derived parameter function in Flowjo. $R$ (F405/488) for exponentially growing cells was used to differentiate cells with low and high $\mathrm{pH}$. The cut-off was defined as the value $(R=0.400)$ dividing the population to two fractions: $1 \%$ lowest percentile (low pHi) and $99 \%$ highest percentile (high $\mathrm{pHi}$ ) of exponentially growing cells. High and low ROS levels were defined similarly as the fluorescence intensity (height) at 585/50 nm dividing the LP-cell population in 1\% lowest percentile (low ROS) and 99\% highest percentiles (high ROS).

\section{Results}

\section{Tolerance to acetic acid is growth phase dependent}

Acetic acid is one of the most important adversaries during fermentation of lignocellulosic substrates. Yeast cells display relatively high tolerance to acetic acid at low $\mathrm{pH}$; however, the level of tolerance depends on several mechanisms that are differently regulated depending on additional extracellular conditions. To shed light on to whether the acetic acid tolerance phenotype can be induced by carbon starvation instead of pre-cultivation in the presence of acetic acid, cells were cultivated in aerobic batch mode in a defined mineral medium and harvested at different growth phases, i.e. at log phase (LP) $(8-12 \mathrm{~h})$, early stationary phase (ESP) $(18-24 \mathrm{~h})$ and late stationary phase $(48 \mathrm{~h})$. In parallel, cells were also pre-cultivated in a medium with $6 \mathrm{~g} \mathrm{~L}^{-1}$ acetic acid at $\mathrm{pH} 5.0$, since this condition was previously shown to induce the desired acid tolerance [11]. Supplementation of acetic acid in the pre-cultivation medium inhibited growth already at $\mathrm{pH} 5.0$, as reflected by an extended diauxic phase as well as a reduced growth rate during glucose assimilation compared to the reference cultivation (Fig. 1a). With a pKa for acetic acid of 4.76, the concentration of undissociated acetic acid experienced by the cells at $\mathrm{pH} 5.0$ was approximately $2.2 \mathrm{~g} \mathrm{~L}^{-1}$. Although growth profiles differed substantially, the final biomass concentrations in the two pre-cultivations were the same with or without acetic acid in the medium. The cells of each of the pre-cultivations were re-inoculated in a new medium supplemented with $6 \mathrm{~g} \mathrm{~L}^{-1}$ acetic acid at $\mathrm{pH}$ 3.7.

The LP-cells not pre-exposed to acetic acid did not proliferate in the new medium (Fig. 1b). The poor tolerance to acetic acid at low $\mathrm{pH}$ was also clear from the poor viability after $24 \mathrm{~h}$ in the new medium (3-4\% of the population). In contrast, pre-adapted cells that were
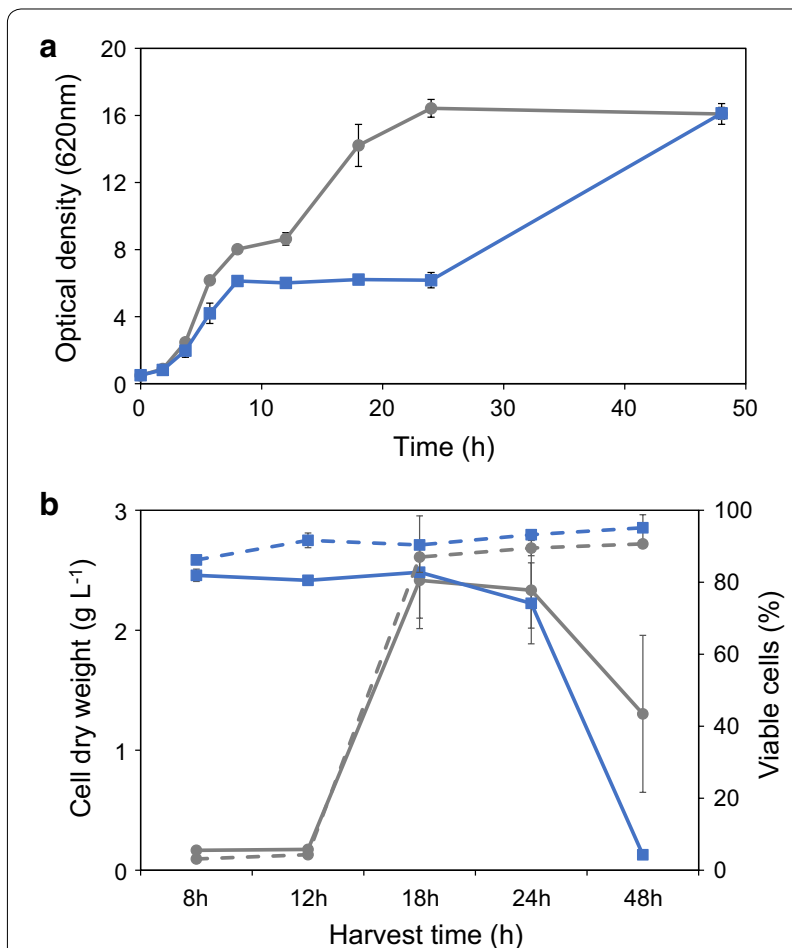

Fig. 1 Yeast response to acetic acid and low $\mathrm{pH}$. a Pre-cultivation of the S. cerevisiae TMB3500 strain in aerobic batch mode in defined mineral medium at $\mathrm{pH} 5.0$ without (round) or with $6 \mathrm{~g} \mathrm{~L}^{-1}$ acetic acid (square). b Cell dry weight (full lines) and \% viability (dotted lines) after $24 \mathrm{~h}$ aerobic batch cultivation in defined mineral medium at pH 3.7 with $6 \mathrm{~g} \mathrm{~L}^{-1}$ acetic acid from pre-cultures at pH 5.0 with (b/ue) and without (grey) $6 \mathrm{~g} \mathrm{~L}^{-1}$ acetic acid. Error bars represent standard error of biological duplicates $(n=2)$

pre-cultured the same length of time $(8-12 \mathrm{~h})$ were able to generate a cell biomass of ca $2.5 \pm 0.1 \mathrm{gdw} \mathrm{L}^{-1}$ and cell viability was around $90 \%$ after $24 \mathrm{~h}$ (Fig. 1b).

The ESP-cells were able to initiate proliferation in the new medium, whether or not they were pre-grown in the presence of acetic acid at $\mathrm{pH}$ 5.0, resulting in a high biomass titre $\left(2.4 \mathrm{gdw} \mathrm{L}{ }^{-1}\right)$ and viability $(87 \%)$ after $24 \mathrm{~h}$. This demonstrates that ESP-cells indeed had an induced acetic acid tolerance. In late SP ( $48 \mathrm{~h}$ pre-cultivation), cells displayed a reduced ability to grow, thus demonstrating a lower tolerance to acetic acid at low $\mathrm{pH}$. However, for this long pre-cultivation time, the biomass titre was substantially lower if cells were pre-adapted than not $(1.30 \pm 0.65$ gdw $\mathrm{L}^{-1}$ vs. $0.13 \pm 0.01 \mathrm{gdw} \mathrm{L}^{-1}$ ). Survival was not correlated to growth for ESP- and late SP-cells, as shown by a high viability (>90\%) even under static conditions (Fig. 1b).

\section{Tolerance of ESP-cell subpopulations to combinations of lignocellulosic inhibitors}

The conditional boundaries of ESP-cells to tolerate lignocellulosic inhibitors at $\mathrm{pH} 3.7$ were further mapped by 
performing a series of cultivations in microtiter plates in media supplemented with different levels of acetic acid, vanillin and furfural according to a $2^{3}$ factorial design (Table 2). In addition, we reasoned that the observed increase in tolerance to acetic acid of ESP-cells was due to their differentiation into Q-cells, which were previously shown to possess increased tolerance to heat shock and oxidative stress compared to NQ-cells [24]. To investigate this further, Q- and NQ-cell subpopulations were separated and both were analysed in parallel with the unsorted ESPcells. Indeed, two cell fractions with different buoyant densities were separated using flotation (Fig. 2), whereas cells in exponential phase cells could not, which is in accordance with the previous studies [24, 25]. When analysed under the microscope, the Q-cells were round without buds in contrast to the NQ-cells that were a heterogeneous mixture of budding and non-budding cells (Fig. 2).
The three cell populations (ESP-cells, Q-cells and NQcells) were each re-inoculated in 15 different medium compositions (M1-M15) and cell growth was monitored for $40 \mathrm{~h}$. Concentration of glucose was low $\left(20 \mathrm{~g} \mathrm{~L}^{-1}\right)$ to avert osmotic stress to the yeast cell and to keep ethanol levels low, thereby removing their inhibitory effect as significant factors on the growth of the populations. Growth was observed in all media except M6, M8, M10 and M14, although the final biomass generated was substantially different (Fig. 3). To distinguish the individual and combinatory effect of inhibitors on growth, a 3-way analysis of variation (ANOVA) was used separately on each dataset generated for each test (Additional file 1: Tables S1-3). The first measured time point (14 h) (Fig. 3a) was used as input for the ANOVA, since the largest effect of these different inocula was observed in the latency phase. From the ANOVAs, it was seen that acetic acid, furfural a



b

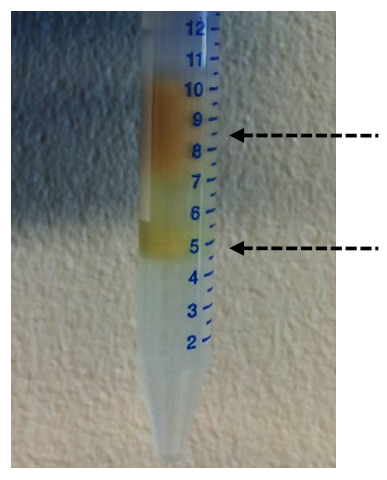

NQ-cells

(upper interphase fraction)

Q-cells

(lower interphase fraction)

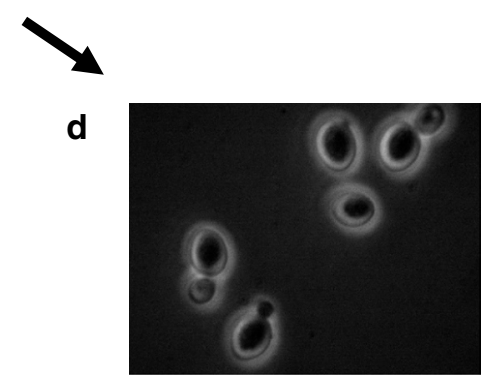

Fig. 2 Separation of S. cerevisiae TMB3500 in ESP using flotation. a Unsorted SP-cells. b Discontinuous density gradient after centrifugation. c Q-cells d NQ-cells

C

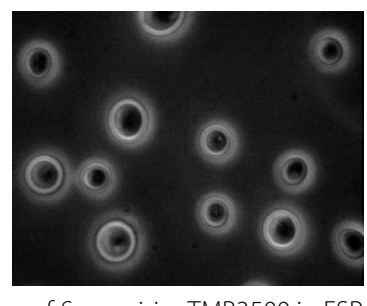

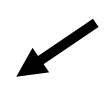

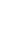



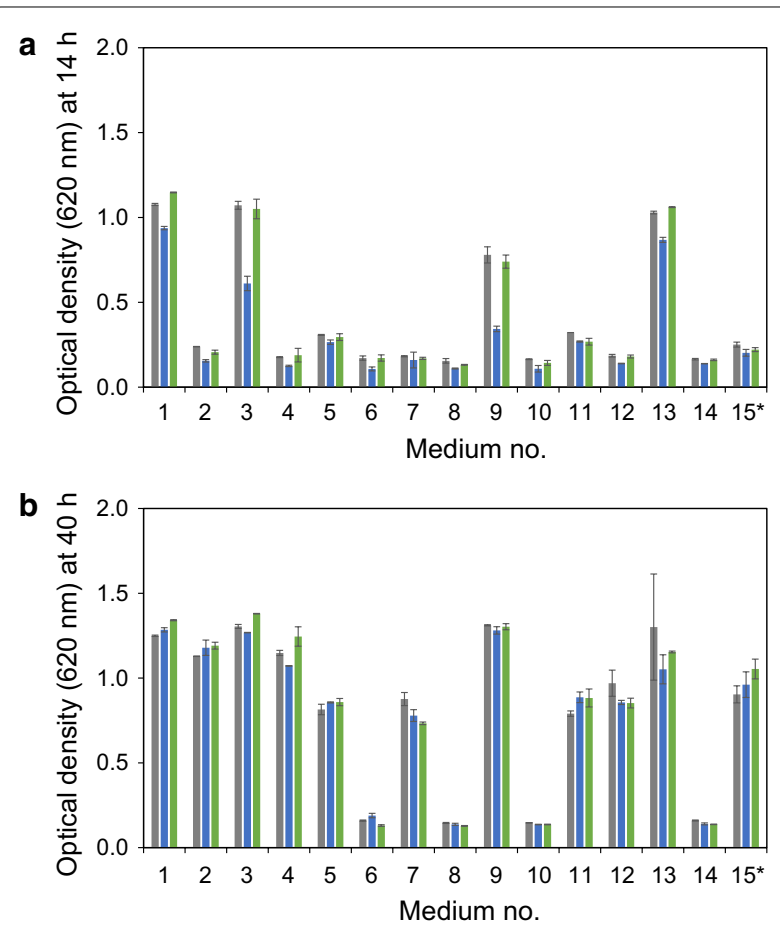

Fig. 3 Cell density after (a) $14 \mathrm{~h}$ and (b) $40 \mathrm{~h}$ cultivation in media M1-M15. Unsorted SP-cells (grey), Q-cells (b/ue) or NQ-cells (green) as inoculum. Error bars represent standard deviation of the mean for biological duplicates $(n=2)$ except for ${ }^{*} \operatorname{M15}(n=18)$

and vanillin inhibited growth significantly $(p<0.001)$ for all inocula, although the effect of furfural was the smallest. The synergistic effect of two inhibitors (acetic acid and vanillin, acetic acid and furfural or vanillin and furfural) on growth was significant in all cases when using Q-cells as inoculum, indicating that this cell subpopulation required a longer latency period under the applied conditions (Additional file 1: Table S2). However, for unsorted ESP-cells and NQ-cells, a combinatorial effect was significant only for acetic acid and vanillin, and none of the combinations with furfural $(p>0.01)$ (Additional file 1: Tables S1 and S3).

A principal component analysis (PCA) of the three datasets combined was made to re-organize the information into new variables [principal components (PC)] that accounted for the majority of the variability in growth (Fig. 4). The input variables were set as yeast responses in terms of biomass formed after $14 \mathrm{~h}$ for the unsorted ESPcells, Q-cells and NQ-cells. PC1 showed 98\% variance with a high positive component loading for all subpopulations (Unsorted ESP-cells, 0.62; Q-cells, 0.44; NQ-cells, $0.65)$, demonstrating that growth of the three inocula was similar in the different media and was in agreement with the ANOVAs. A variation between the inocula was, however, seen in PC2 (2\%), where Q-cells had a positive component loading (0.88), whereas the unsorted ESPcells and NQ-cells were more similar to each other and had a slightly negative loading for biomass titre (unsorted ESP-cells, -0.42; NQ-cells, -0.22). From the score plot, it could be read that the largest influence of the different behaviour of Q-cells compared to ESP-cells and NQ-cells in both $\mathrm{PC} 1$ and $\mathrm{PC} 2$ was from growth in media M1, M3, M9 and M13, while the other media clustered together.

To further analyse potential differences between the three inocula, lag times, maximum growth rates and the final biomass in an intermediate inhibitory medium (3.5 $\mathrm{g} \mathrm{L}^{-1}$ acetic acid, $1 \mathrm{~g} \mathrm{~L}^{-1}$ furfural and $1 \mathrm{~g} \mathrm{~L}^{-1}$ vanillin) were estimated by fitting the modified Gompertz equation (Eq. 1) [33] to the experimental data

$$
y=A \exp \left\{-\exp \left[\frac{\mu_{\max } \times e}{A}(\lambda-1)+1\right]\right\}
$$

where $y$ is the logarithm of the relative population size $\left[\ln \left(N / N_{0}\right)\right], A$ is the asymptote $\left[\ln \left(N_{\infty} / N_{0}\right)\right], \mu_{\max }$ is the maximum specific growth rate $\left(\mathrm{h}^{-1}\right), \lambda$ is the lag time (h), $e$ is $\exp (1)$ and $t$ is time (h).

Modelling of growth responses for unsorted ESP-, Qand NQ-cells revealed a small difference in lag time (18 and 7\% longer for Q-cells than for unsorted ESP-cells and NQ-cells, respectively, $p<0.001$ ) (Table 3; Additional file 2: Figure $\mathrm{S} 1$ ). The maximum specific growth rate and the asymptote, $\mathrm{A}$, were similar for the different inocula, meaning that once growth started the specific condition rather than the history of the population determined the growth rate and biomass yield.

Altogether the different analyses pointed towards that the shift into Q-cells was not determining the enhanced ability of ESP-cells to grow in the presence of inhibitors. In contrast, the trend was towards longer lag phases for Q-cells than for NQ-cells. On the other hand, since the lag time is determined by the number of viable cells at the start, it could also be that Q-cells were less tolerant to the inhibitors resulting in an initial drop in viability. However, FCM analysis after incubation for $24 \mathrm{~h}$ in static media demonstrated that cell viability was similar for unsorted ESP-cells, Q- and NQ-cells (Fig. 5). For medium M14 cell viability was substantially lower than for the other static media, demonstrating that this specific combination of inhibitors was most toxic.

\section{Intracellular $\mathrm{pH}$ distribution responses to lignocellulosic inhibitors at low external pH}

Determining viability might not be an appropriate means to distinguish the ability to initiate growth in the presence of lignocellulosic inhibitors at low $\mathrm{pH}$ as viability of cells in static media remained also very high. Instead, the number of cells that are capable to maintain their pHi may be a better measure to predict the occurrence 


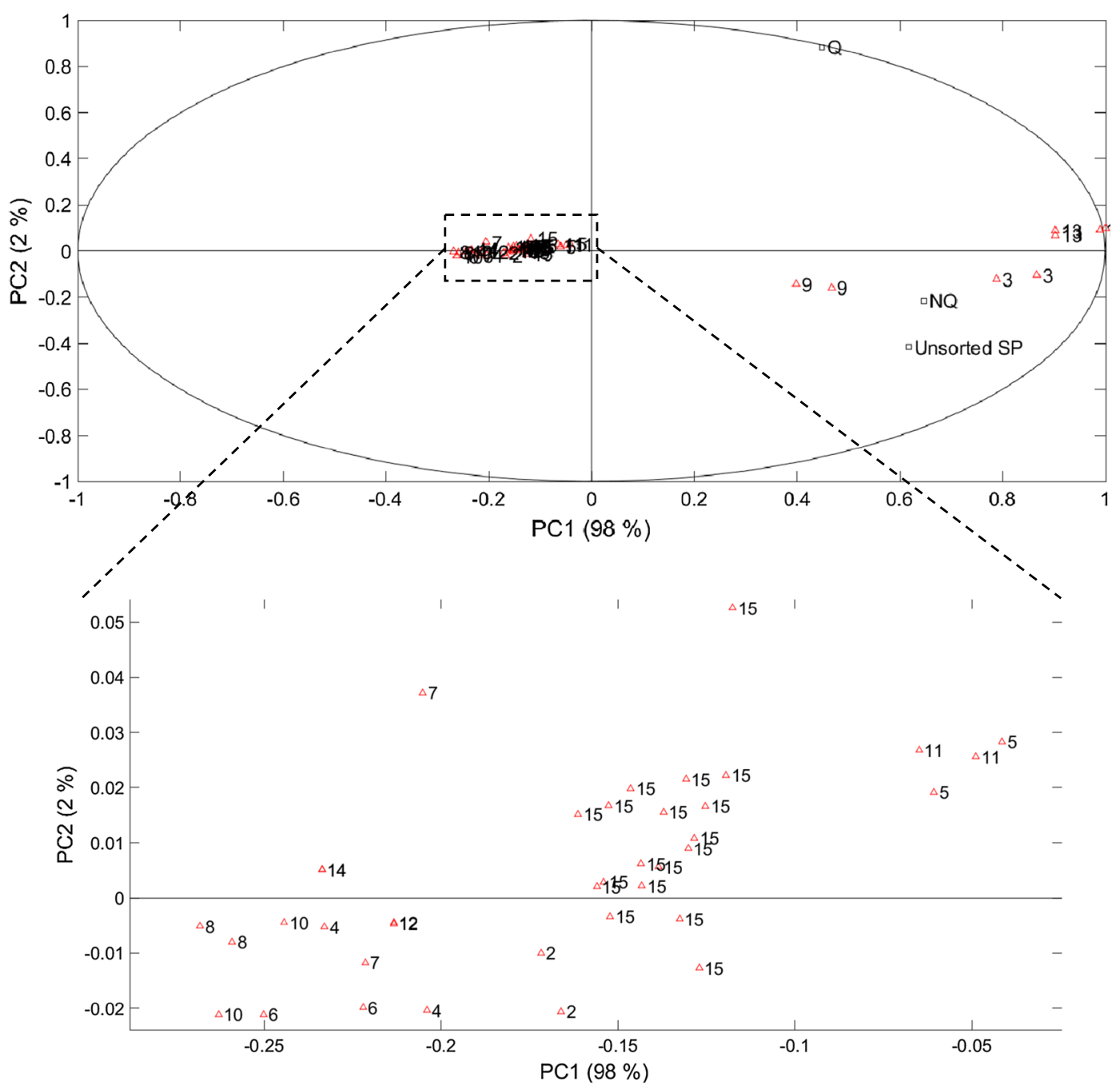

Fig. 4 PCA analysis of factorial design experiment using unsorted SP-, Q- or NQ-cells as inoculum. Loading plot (squares) and Score plot (triangles)

Table 3 Fitting of the Gompertz equation to experimental data obtained for cultivation in medium $15(n=18)$

\begin{tabular}{llll}
\hline Inoculum & Lag time $\boldsymbol{\lambda}(\mathbf{h})$ & Max. Growth rate $\boldsymbol{\mu}_{\mathbf{m a x}}\left(\mathbf{h}^{\mathbf{- 1}}\right)$ & Final population size $\boldsymbol{A} \ln \left(\mathbf{O D} / \mathbf{O D}_{\mathbf{0}}\right)$ \\
\hline Unsorted ESP-cells & $10.6 \pm 1.3$ & $0.18 \pm 0.01$ & $1.9 \pm 0.3$ \\
Q-cells & $12.6 \pm 0.8$ & $0.17 \pm 0.01$ & $2.0 \pm 0.2$ \\
NQ-cells & $11.8 \pm 0.3$ & $0.18 \pm 0.01$ & $2.1 \pm 0.1$ \\
\hline
\end{tabular}

of growth when exposed to the harsh conditions. In a previous study, it was found that growth in the presence or absence of acetic acid at low extracellular $\mathrm{pH}$ correlated with the number of cells maintaining their $\mathrm{pHi}$ $[38,39]$. To test this for ESP-cells, the response in $\mathrm{pHi}$ distribution in a CEN.PK strain over-expressing recombinant pHluorin was measured at lignocellulosic conditions by using ratiometric flow cytometry. Furthermore, measuring the response at the single-cell level could reveal any discrepancies in tolerance distribution within the different pre-culture populations.

The CEN.PK background was chosen because it is a well-established model strain for physiological studies within the yeast community [40], and it allowed for easy introduction of the pHluorin reporter system using the URA3 marker. Further, it was previously established that 


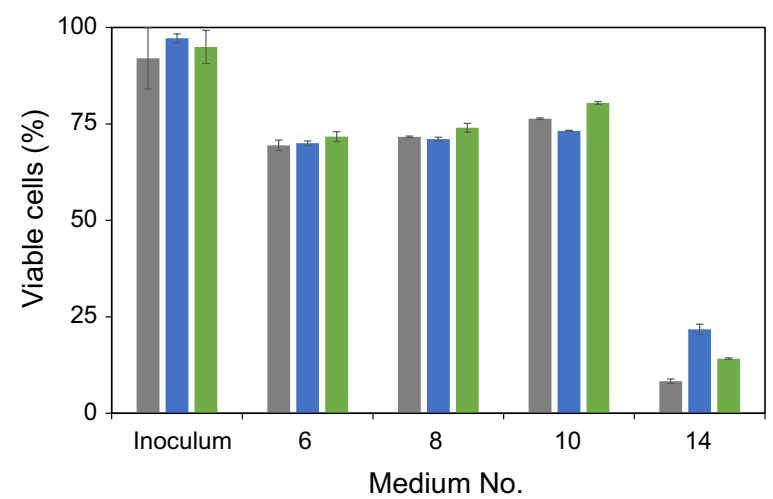

Fig. 5 Cell viability after $24 \mathrm{~h}$ incubation in medium supplemented with different amounts of acetic acid, vanillin and furfural at pH 3.7. SP-cells (grey), Q-cells (blue) and NQ-cells (green). Error bars represent standard error of biological duplicates $(n=2)$

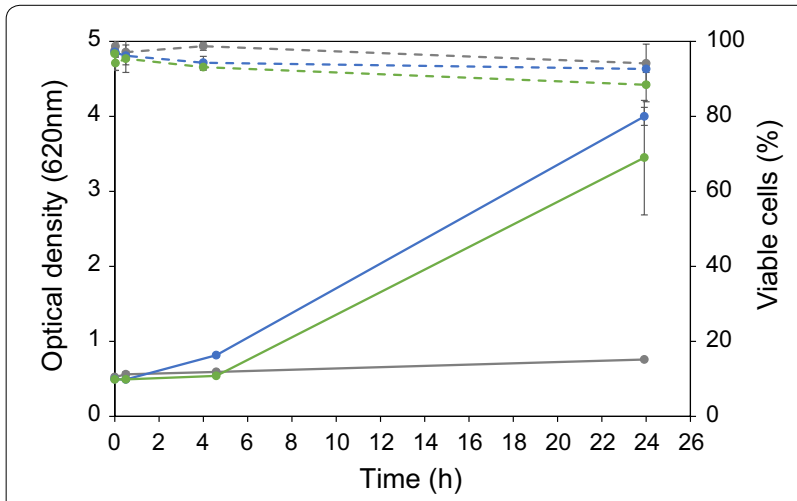

Fig. 6 Effect of pre-cultivation on subsequent cultivation of yeast (CEN.PK 113-5D expressing pHluorin, TMB3800) in inhibitory medium. OD620 (full lines) and viability (dotted lines) as a function of cultivation time for the following inocula: LP-cells (grey), pre-adapted cells (blue) and ESP-cells (green). Error bars represent standard error of biological duplicates $(n=2)$

induction of acetic acid tolerance at low $\mathrm{pH}$ is displayed both in TMB3500 and in the laboratory strain CEN.PK 113-7D [11], and is thus strain-independent.

The CEN.PK strain was pre-cultured with or without acetic acid at pH 5.0, harvested in LP or in ESP and subsequently re-inoculated in defined mineral medium supplemented with $6 \mathrm{~g} \mathrm{~L}^{-1}$ acetic acid, $0.2 \mathrm{~g} \mathrm{~L}^{-1}$ vanillin and $0.75 \mathrm{~g} \mathrm{~L}^{-1}$ furfural at $\mathrm{pH} 4.5$. Variation in pre-cultivation conditions indeed resulted in significant differences in growth profiles (Fig. 6, Additional file 3: Figure S2). LPcells did not grow in the presence of inhibitors within the measured time interval of $24 \mathrm{~h}$; it only grew in the control medium at $\mathrm{pH} 5.0$ without supplementation of inhibitors (Additional file 4: Figure S3). Loss of viability could not explain the lack of growth for LP-cells since viability slightly reduced to about $85 \%$ during the first hour after which this level remained throughout the cultivation (Fig. 6). However, the number of LP-cells with kept physiological pHi had drastically reduced (Fig. 7a, e). Between the time of inoculation and before stable acquisition of cells in the FCM analysis ( $2 \mathrm{~min}$ ), $95 \%$ of the population had a reduction in the fluorescence ratio from 0.54 to 0.25 (Fig. $7 \mathrm{a}, \mathrm{d}, \mathrm{e}$ ). This demonstrates that nearly the total LP-cell population was sensitive to the inhibitory medium. Interestingly, a subpopulation $(34 \pm 27 \%)$ with a transiently higher ratio was observed after $30 \mathrm{~min}$, but after $4 \mathrm{~h}$ the frequency of cells with high pHi was close to zero (Fig. 7a, d, e).

Cells from the pre-adapted inoculum had a lower initial pHi than LP-cells in the medium without inhibitors (Fig. 7b, d, e). As cells were transferred to the medium with inhibitors at $\mathrm{pH} 4.5$, a majority of the population (78 $\pm 1 \%)$ recovered to a higher $\mathrm{pH}$ and maintained it under the measured time period (Fig. 7b, d, e). The more uniform pHi response to the shift in environment and the low fraction of cells with low $\mathrm{pHi}$ indicates that inhibitor tolerance was relatively homogenously distributed within the pre-adapted cell population.

Finally, cell populations in ESP cultures displayed a high degree of heterogeneity with a high frequency of cells with low pHi prior to inhibitor exposure (Fig. 7c-e). Upon transfer to the inhibitory medium, a distinct subpopulation had an increase in ratio to a similar level as those from the pre-adapted cells, while a majority of cells kept a low pHi over the 4-h incubation period. Despite this, cells with low $\mathrm{pH}$ were still viable as measured with FCM analysis of PI-stained cells (Fig. 6). Altogether, this indicates that the ability of ESP populations to initiate growth under lignocellulosic conditions is only present in a fraction of the cells.

\section{ROS level distribution responses to lignocellulosic inhibitors at low external pH}

Low ROS levels have previously been associated with cell tolerance to multiple stress factors, e.g. exposure to furfural [41] or oxidative stress from hydrogen peroxide [42]. Therefore, we hypothesized that the ability to quench ROS contributes favourably to an acquired inhibitor tolerance observed herein for pre-adapted and ESP-cells. To verify this, population responses to exposure to the mixture of lignocellulosic inhibitors at low $\mathrm{pH}$ were analysed by FCM. It was found that all cultures consisted of cells with high or low ROS levels (Fig. 8), although the subpopulation distribution differed considerably (Fig. 8a-c, f). Mean ROS levels were ca. twofold higher for LP-cells than for pre-adapted cells and ESPcells (Fig. 8d). As cells were transferred to the inhibitory environment, a subpopulation of the pre-adapted 

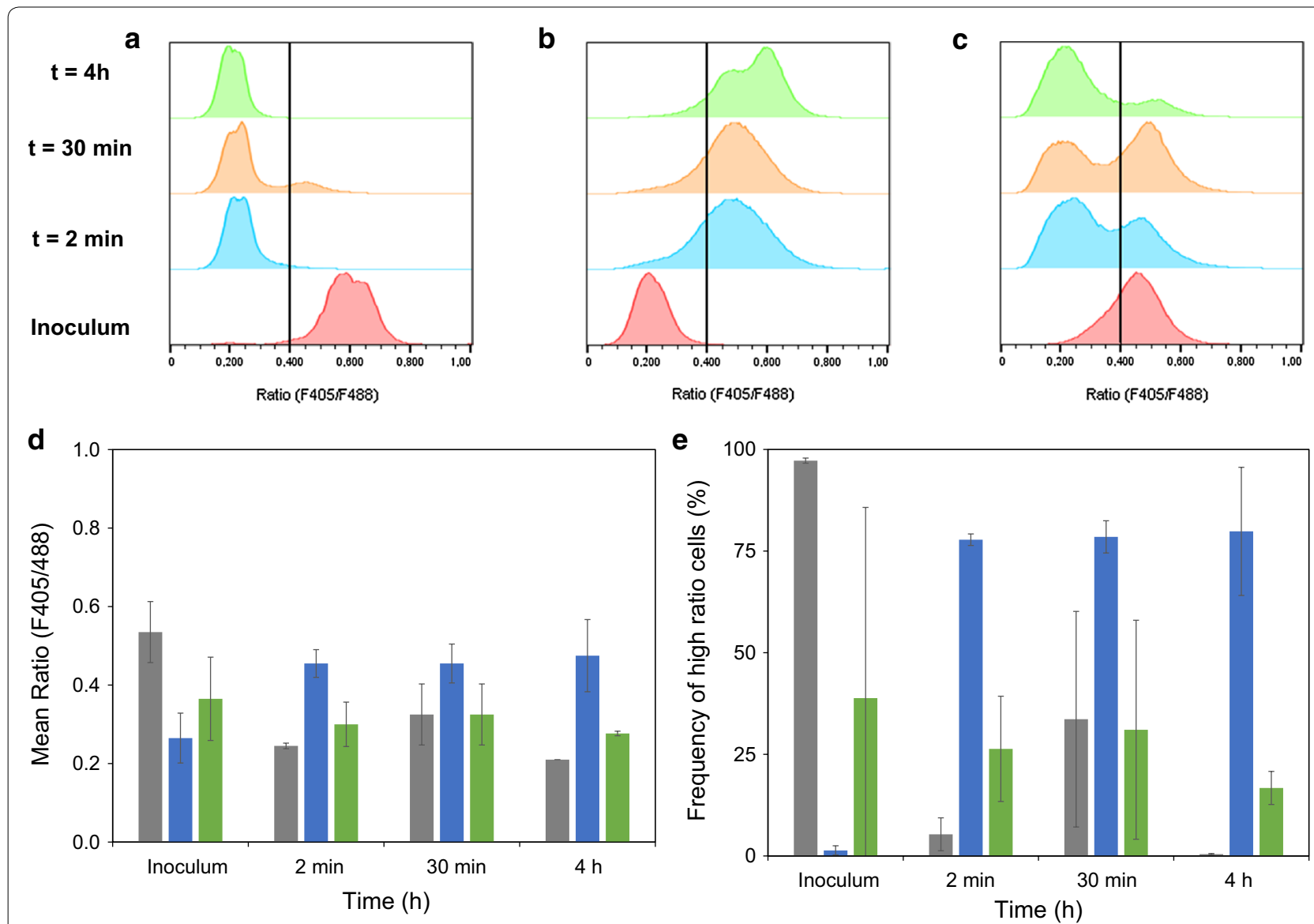

Fig. 7 Evolution of pHi in different yeast cell inocula (CEN.PK 113-5D expressing pHluorin, TMB3800) upon exposure to a mixture of lignocellulosic inhibitors. Representative histograms from the following inocula: $\mathbf{a} L \mathrm{LP}$-cells, $\mathbf{b}$ cells pre-adapted in medium supplemented with the inhibitors at $\mathrm{pH}$ 5 , and $\mathbf{c}$ ESP-cells. The vertical line displays cells with high and low ratio (F405/F488) and was defined as the number (=0.400) separating LP-cells (a, inoculum) into fractions of $1 \%$ lowest and $99 \%$ highest percentiles. d Mean ratio (F405/F488) and e frequency of cells with high ratio (>0.400) for the three different inocula (LP-cells, grey bars; pre-adapted cells, blue bars; ESP-cells, green bars) measured over time. Error bars represent standard error of biological duplicates $(n=2$ ). Ratio (F405/F488) is the ratio of pHluorin fluorescence emission collected at 542/50 and 533/30 nm originating from excitation at 405 and $488 \mathrm{~nm}$, respectively. Ratiometric flow cytometry measurement was performed with a Moflo cell sorter and data analysis was performed with Flowjo

inoculum had a dramatic reduction (ca 3-fold) in ROS levels already within 2 min, whereas a slight increase was observed for LP-cells. ESP-cells displayed a higher degree of heterogeneity (Fig. 8e) and had a large cell fraction with low ROS levels (Fig. 8c, f) that was more stable than for the other two inocula over the measured time period. After $4 \mathrm{~h}$, the differences between the inocula were levelled out, i.e. ROS levels for LP-cells were significantly reduced, while they were slightly increased for the pre-adapted cells (Fig. 8d).

\section{Discussion}

ESP-cells displayed increased tolerance to lignocellulosic inhibitors at low $\mathrm{pH}$

In this study, we demonstrated that early stationary phase cells have an increased tolerance to a combination of acetic acid, vanillin and furfural at low $\mathrm{pH}$, as were reflected in immediate ability to initiate growth. The tolerance of ESP-cells was in range with the tolerance obtained by pre-adaptation in moderately inhibitory conditions. This was in stark contrast with exponentially growing cells that displayed a higher sensitivity towards all tested inhibitors. Allowing cells to enter ESP in the pre-cultivation step may therefore be beneficial from a process perspective as it will shorten the latency phase of the fermentation. It is well established from the previous studies that ESP-cells have high tolerance towards multiple stress factors $[17,19,20]$. Although the underlying mechanism behind tolerance is specific for each stress factor, cross-tolerance to different stressors is often observed and is generally ascribed to induction of the ESR upon nutrient depletion. 

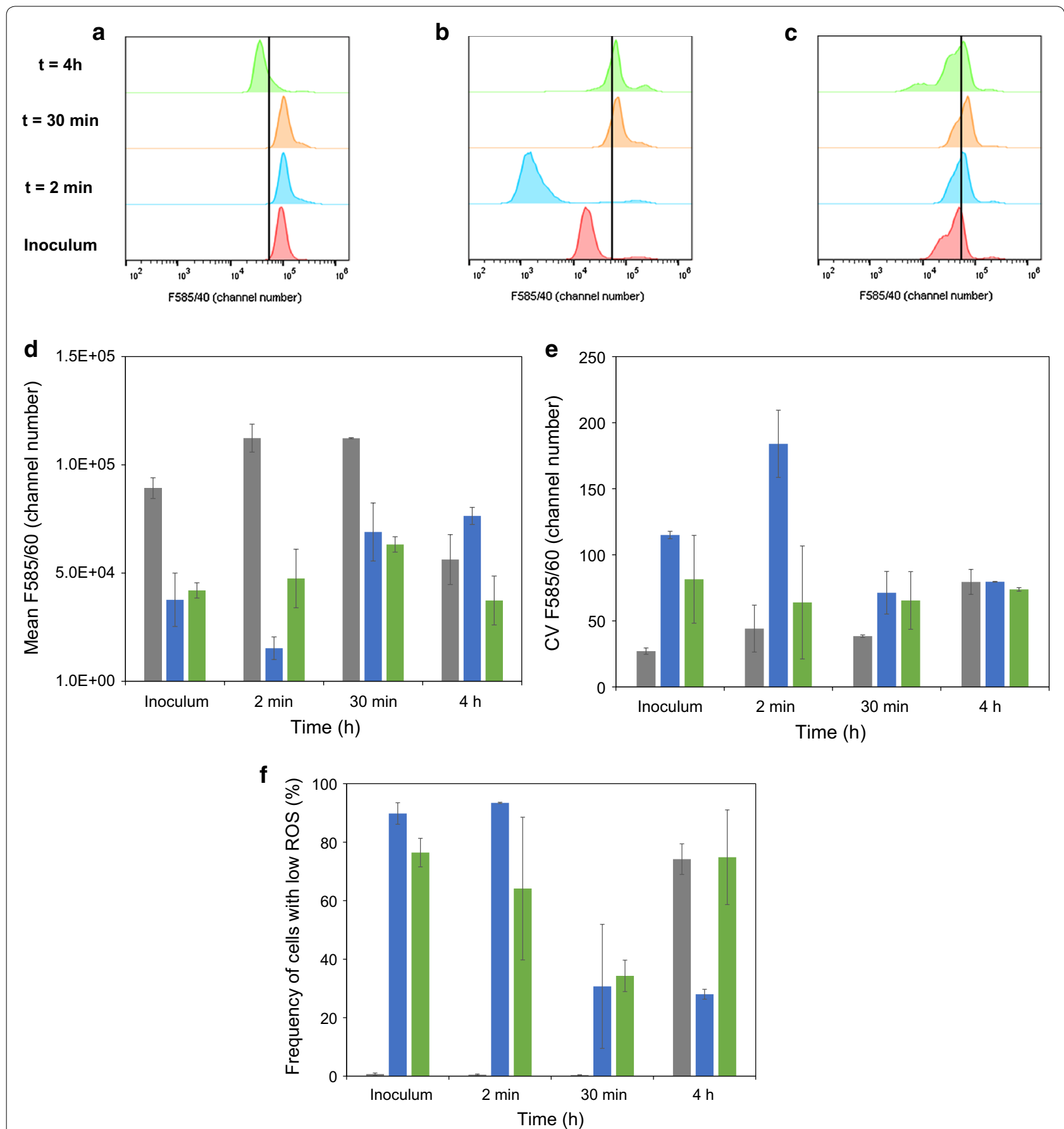

Fig. 8 Evolution of ROS in different yeast cell inocula (CEN.PK 113-7D) upon exposure to a mixture of lignocellulosic inhibitors. Representative histograms from the following inocula: a LP-cells, b cells pre-adapted in medium supplemented with the inhibitors at pH 5 and $\mathbf{c}$ ESP-cells. The vertical line displays cells with high and low ROS levels and was defined as the number (F585/40 $=52 \times 10^{4}$ channel number) separating the LPcells (a, inoculum) into fractions of 1\% lowest and 99\% highest percentiles. d Mean F585/40 and e coefficient of variation (CV) of F585/40 for the three different inocula (LP-cells, grey; pre-adapted cells, blue; ESP-cells, green) measured over time. f Frequency of cells with low ROS levels over time. Error bars represent standard error of biological duplicates $(n=2)$. F585/40 is DHE fluorescence emission collected at $585 / 30 \mathrm{~nm}$ originating from excitation at $488 \mathrm{~nm}$, respectively. Flow cytometry measurement was performed with a BD Accuri instrument and data analysis was performed with Flowjo. Histograms are from a representative experiment 


\section{Inhibitor tolerance was similar for Q- and NQ-cells in ESP populations}

SP-cells were previously found to consist of two subpopulations with distinct physiological state, i.e. the so-called Q- and NQ-cells [24]. The cell fractions can easily be separated from each other based on differences in buoyant cell density $\left(\delta_{\mathrm{Q}}=1.14 \mathrm{~g} \mathrm{~L}^{-1}\right.$ and $\left.\delta_{\mathrm{NQ}}=1.10 \mathrm{~g} \mathrm{~L}^{-1}\right)$, for example, by density gradient centrifugation [24] or by flotation as described in the present study. Q-cells consists of young mother cells and unbudded daughter cells and was previously shown to have high mitochondrial activity, low ROS levels, high levels of reserve carbohydrates (glycogen and trehalose), and a high ability to re-enter the cell cycle upon nutrient-rich conditions. NQ-cells, on the other hand, are more heterogeneous and consist of cells with genomic instability, high levels of ROS, non-functional mitochondria and display apoptotic characteristics. With regard to stress tolerance, Q-cells possess higher ability to withstand heat shock and carbon starvation than NQ-cells $[24,26]$. We therefore reasoned that the higher ability of ESP-cells to initiate growth in the presence of lignocellulosic inhibitors at low $\mathrm{pH}$ was due to differentiation into Q-cells. However, the ability of Q-cells to proliferate and remain viable was rather similar to that of NQ-cells under the whole range of tested conditions in our study. It follows that differentiation into Q-cells was not the underlying cause for improved tolerance of ESP-cells. Engineering of Q/ NQ distributions in the pre-cultivation step may therefore not be a way forward to minimize the lag phase of a lignocellulosic fermentation process. Q-cells actually had a slight prolongation of the lag phase upon inoculation to new medium, which may be due to that they are arrested in the $G_{0}$ phase, and once nutrients are provided they require time for metabolic and structural rearrangements before entering the mitotic cell cycle. NQ-cells on the other hand are arrested in different phases of the cell cycle without clear preference for a specific phase, and did not require the same time before initiating proliferation. Furthermore, any negative effect of long-term starvation of NQ-cells, as observed previously [26], was not observed in ESP. It can be deduced from our results that cells in late SP would behave differently compared to ESP-cells.

\section{Vanillin was biocidal in combination with acetic acid at low pH}

Yeast was sensitive to all tested inhibitors, although the degree of inhibition differed depending on the physiological state of the population. Acetic acid and vanillin were most detrimental for cell fitness, while furfural was inhibiting to a lesser extent at the concentration range used in the present study. The latter was probably due to an inherent high capacity of yeast to reduce furfural to the corresponding non-inhibitory alcohol, since preadapted cells behaved similarly to ESP-cells despite having a manifold higher specific furfural reductase activity (Additional file 5: Figure S3). It cannot be ruled out that the mechanisms behind the acquired inhibitor tolerance were different between pre-adapted cells and ESP-cells, and that furfural detoxification contributed favourably to the former. Inhibition was in most cases static rather than cidal, except for the combination of high amounts of vanillin $\left(1.84 \mathrm{~g} \mathrm{~L}^{-1}\right)$ and moderate levels of acetic acid $\left(3.5 \mathrm{~g} \mathrm{~L}^{-1}\right)$. At these concentrations, both vanillin and acetic acid were static on their own despite the low $\mathrm{pH}$ (3.7). The static effect of vanillin has been described previously [43], but herein we demonstrated that it is biocidal in combination with acetic acid at low $\mathrm{pH}$. The underlying reasons for this is yet unknown, but it can be speculated that above a threshold concentration vanillin will inhibit carbon metabolism, resulting in an inability of the cell to efflux dissociated acetic acid and to keep $\mathrm{pH}$ homeostasis. Hence, the combination of vanillin and acetic acid has a synergistic effect on growth inhibition. Furthermore, our results indicated that furfural and acetic acid had a lower synergistic effect on growth inhibition. This is in contrast to a previous study on the combinatorial effect of different inhibitors (acetic acid, furfural and p-hydroxybenzaldehyde) in which it was found that furfural and acetic acid interacted synergistically on cell growth and ethanol production [44].

\section{Tolerant cultures displayed characteristic population responses in $\mathrm{pHi}$ and $\mathrm{ROS}$}

Process control of yeast fitness distributions during fermentation requires identification of correlations between critical process parameters and cell properties that can be rapidly monitored at the single-cell level, such as with flow cytometry $[45,46]$. Here we looked into pHi and ROS formation as two cell properties that correlate with inhibitor stress tolerance in yeast.

\section{FCM measurement of intracellular $\mathrm{pH}$}

ESP-cells consist of two subpopulations with differences in intracellular $\mathrm{pH}$, and addition of glucose in non-inhibitory medium results in recovery of physiological $\mathrm{pH}$ for the entire population [37]. By measuring responses in intracellular $\mathrm{pH}$ distribution as cells were transferred from the pre-culture to the inhibitory medium, we observed that only a subpopulation of ESP-cells was able to maintain their $\mathrm{pHi}$. This implicates that inhibitor tolerance of ESP cultures lies at the level of a subpopulation. A similar behaviour was previously observed for Zygosaccharomyces bailii, which was shown to have a 1000 -fold higher fraction of cells in ESP that was tolerant to weak 
organic acids, e.g. benzoic acid, sorbic acid and acetic acid, than exponentially growing cells [18]. Tolerance to acetic acid has previously been found to correlate to the cell pHi prior to exposure of the stress [47]. In our case, the average pHi of the ESP-cells was lower than for LP-cells, which is in agreement with the previous studies $[30,37]$. Pre-adapted cells also had a lower pHi than LPcells and a majority of the population was able to recover physiological $\mathrm{pH}$ within $2 \mathrm{~min}$. Low pHi may be beneficial due to a lower amount of dissociated acid in the cytoplasm at the moment the cells are exposed to the harsh lignocellulosic conditions. It is unclear how cells with initially low $\mathrm{pHi}$ are able to rapidly restore intracellular $\mathrm{pH}$, as was the case for pre-adapted cells and a subpopulation of the ESP-cells (Fig. 7). Maintaining physiological pH is a requirement for a functional glycolysis [48], enabling ATP-driven proton export to keep pH homeostasis under acidic condition (see review [49]). Rapid reduction in free inorganic phosphate due to the formation of fructose bisphosphate may play a role in bringing the $\mathrm{pHi}$ to neutral as was monitored in Lactococcus lactis (see review by [50]). Yet, there might be other specific mechanisms contributing to the reduction of acetic acid stress in combination with vanillin and furfural.

\section{FCM measurement of ROS levels}

A correlation between inhibitor tolerance and a high frequency of cells with low ROS levels was observed. This may be due to an increased capacity of inhibitor tolerant populations to quench ROS that was formed spontaneously or as a consequence of inhibitor exposure [41]. ROS are formed continuously in mitochondria under aerobic conditions, and are generally at higher level in exponentially growing cells than in SP-cells [51]. This may explain the observed discrepancies in inhibitor tolerance that were observed between pre-adapted cells, LPcells and ESP-cells. The lower ROS levels of pre-adapted cells may be caused by inhibitor-specific mechanisms, for example, by an increased ability to reduce furfural by an induced furfural reductase activity. Another contributing factor may be an increased level of glutathione, which scavenges ROS by non-enzymatic oxidation, and is involved in maintaining redox homeostasis in the cell via NADPH-dependent glutathione reductase (GLR1) [52]. It was previously shown that by increasing intracellular glutathione levels by over-expression, the gene coding for $\gamma$-glutamylcysteine synthetase (GST1) resulted in improved growth in non-detoxified spruce hydrolysate [53]. An alternative way to reduce ROS levels is to introduce a biosynthetic pathway to L-ascorbic acid (vitamin C) that functions as a scavenger for oxygen radicals [54]. Our results give support to reduction of ROS levels as a suitable target for improving tolerance to inhibitors.

\section{Conclusions}

In this study, we demonstrate that cells in early stationary phase have increased tolerance to lignocellulosic inhibitors at low $\mathrm{pH}$. Thus, allowing cells to enter ESP by carbon starvation during pre-cultivation may be a useful strategy to improve productivity in batch processes that are based on actively growing cells as biocatalysts for bioconversions that are limited by high amounts of inhibitors and low $\mathrm{pH}$. Furthermore, flow cytometry as means to characterize population response profiles has demonstrated to be a sophisticated tool for prediction of yeast behaviour. Herein, we found that FCM-measured frequency of cells that recovered $\mathrm{pHi}$ and kept low ROS levels correlated with the ability of the yeast culture to initiate growth in harsh lignocellulosic conditions.

\section{Additional files}

Additional file 1. ANOVA:s of factorial design experiment using unsorted ESP-, Q- or NQ-cells as inoculum.

Additional file 2. Fitting of the Gompertz equation to experimental data obtained for unsorted ESP-cells, Q-cells and NQ-cells.

Additional file 3. Viability and growth of CEN.PK 113-7D (w/o pHluorin) in defined medium supplemented with lignocellulosic inhibitors.

Additional file 4. Growth and fluorescence of CEN.PK 113-5D expressing pHluorin (TMB3800)

Additional file 5. Specific furaldehyde reductase activity in crude cell extracts.

\section{Abbreviations}

LP: Log phase; ESP: Early stationary phase; SP: Stationary phase; Q: Quiescent; NQ: Non-quiescent; pHi: Intracellular $\mathrm{pH}$; ROS: Reactive oxygen species; ESR: Environmental stress response; FCM: Flow cytometry.

\section{Authors' contributions}

VN, MGG and EN participated in the design of the study. JS participated in the design of flotation experiments for the characterization of quiescent cells. VN and MC performed the experimental work and wrote the manuscript. MC conceived the study, and participated in the design and coordination of the study. All the authors read and approved the final manuscript.

\section{Acknowledgements}

We would like to thank Prof. Gertien Smits (University of Amsterdam, The Netherlands) for kindly providing us with the pHluorin plasmid. We would also like to thank Tim Berglund and Andreas Toytziaridis for technical assistance in strain cultivations, and Dr. Lisa Wasserstrom (Lund University) for construction of the pHluorin-expressing strain.

\section{Competing interests}

The authors declare that they have no competing interests.

\section{Availability of data and materials}

The datasets supporting the conclusions of this article are included within the article. Strains constructed in the current study are available from the corresponding author on request.

\section{Funding}

This work was financed by the Swedish Energy Agency (Energimyndigheten) (Grant Number P35350-1) and the Swedish Research Council FORMAS (Grant Number 229-2011-1052). 


\section{Publisher's Note}

Springer Nature remains neutral with regard to jurisdictional claims in published maps and institutional affiliations.

Received: 14 February 2017 Accepted: 18 April 2017

Published online: 04 May 2017

\section{References}

1. Zhu JY, Pan XJ. Woody biomass pretreatment for cellulosic ethanol production: Technology and energy consumption evaluation. Bioresource Technol. 2010;101:4992-5002.

2. Limayem A, Ricke SC. Lignocellulosic biomass for bioethanol production: current perspectives, potential issues and future prospects. Prog Energy Combust Sci. 2012;38:449-67.

3. Margeot A, Hahn-Hagerdal B, Edlund M, Slade R, Monot F. New improvements for lignocellulosic ethanol. Curr Opin Biotech. 2009;20:372-80.

4. Chandel AK, Da Silva SS, Singh OV. Detoxification of lignocellulose hydrolysates: biochemical and metabolic engineering toward white biotechnology. Bioenerg Res. 2013;6:388-401.

5. Piotrowski JS, Zhang Y, Sato T, Ong I, Keating D, Bates D, Landick R. Death by a thousand cuts. the challenges and diverse landscape of lignocellulosic hydrolysate inhibitors. Front Microbiol. 2014;5:90.

6. Almeida JRM, Runquist D, Sànchez Nogué V, Lidén G, Gorwa-Grauslund MF. Stress-related challenges in pentose fermentation to ethanol by the yeast Saccharomyces cerevisiae. Biotechnol J. 2011;6:286-99.

7. Caspeta L, Castillo T, Nielsen J. Modifying yeast tolerance to inhibitory conditions of ethanol production processes. Front Bioeng Biotechnol. 2015;3:184.

8. Petersson A, Almeida JR, Modig T, Karhumaa K, Hahn-Hagerdal B, GorwaGrauslund MF, Lidén G. A 5-hydroxymethyl furfural reducing enzyme encoded by the Saccharomyces cerevisiae ADH6 gene conveys HMF tolerance. Yeast. 2006;23:455-64

9. Modig T, Almeida JR, Gorwa-Grauslund MF, Lidén G. Variability of the response of Saccharomyces cerevisiae strains to lignocellulose hydrolysate. Biotechnol Bioeng. 2008;100:423-9.

10. Shen Y, Li HX, Wang XN, Zhang XR, Hou J, Wang LF, et al. High vanillin tolerance of an evolved Saccharomyces cerevisiae strain owing to its enhanced vanillin reduction and antioxidative capacity. J Ind Microbiol Biotech. 2014;41:1637-45.

11. Sànchez i Nogué V, Narayanan V, Gorwa-Grauslund M. Short-term adaptation improves the fermentation performance of Saccharomyces cerevisiae in the presence of acetic acid at low pH. Appl Microb Biotechnol. 2013:97:7517-7525.

12. Fernandes AR, Mira NP, Vargas RC, Canelhas I, Sá-Correia I. Saccharomyces cerevisiae adaptation to weak acids involves the transcription factor Haa1p and Haa1 p-regulated genes. Biochem Bioph Res Co. 2005;337:95-103

13. Swinnen S, Henriques SF, Shrestha R, Ho PW, Sá-Correia I. Improvement of yeast tolerance to acetic acid through Haal transcription factor engineering: towards the underlying mechanisms. Microb Cell Fact. 2017;16:7.

14. Nielsen F, Tomas-Pejo E, Olsson L, Wallberg O. Short-term adaptation during propagation improves the performance of xylose-fermenting Saccharomyces cerevisiae in simultaneous saccharification and co-fermentation. Biotechnol Biofuels. 2015:8:219.

15. Narayanan V. Sànchez i Nogué V, van Niel EW, Gorwa-Grauslund MF: Adaptation to low $\mathrm{pH}$ and lignocellulosic inhibitors resulting in ethanolic fermentation and growth of Saccharomyces cerevisiae. AMB Express. 2016;6:59.

16. Zakrzewska A, van Eikenhorst G, Burggraaff JE, Vis DJ, Hoefsloot H, Delneri $D$, et al. Genome-wide analysis of yeast stress survival and tolerance acquisition to analyze the central trade-off between growth rate and cellular robustness. Mol Biol Cell. 2011;22:4435-46.

17. Lewis JG, Learmonth RP, Watson K. Role of growth phase and ethanol in freeze-thaw stress resistance of Saccharomyces cerevisiae. Appl Environ Microbiol. 1993;59:1065-71.

18. Stratford M, Steels H, Nebe-von-Caron G, Avery SV, Novodvorska M, Archer DB. Population heterogeneity and dynamics in starter culture and lag phase adaptation of the spoilage yeast Zygosaccharomyces bailii to weak acid preservatives. Int J Food Microbiol. 2014;181:40-7.
19. De Melo HF, Bonini BM, Thevelein J, Simões DA, Morais MA. Physiological and molecular analysis of the stress response of Saccharomyces cerevisiae imposed by strong inorganic acid with implication to industrial fermentations. J Appl Microbiol. 2010;109:116-27.

20. Werner-Washburne M, Braun EL, Crawford ME, Peck VM. Stationary phase in Saccharomyces cerevisiae. Mol Microbiol. 1996;19:1159-66.

21. Carlquist $M$, Fernandes RL, Helmark S, Heins AL, Lundin L, Sorensen SJ, et al. Physiological heterogeneities in microbial populations and implications for physical stress tolerance. Microb Cell Fact. 2012;11:94.

22. Gasch A. The environmental stress Response: a common yeast response to diverse environmental stresses. In Topics in Current Genetics. 2003;2:11-70

23. Smets B, Ghillebert R, De Snijder P, Binda M, Swinnen E, De Virgilio C, Winderickx J. Life in the midst of scarcity: adaptations to nutrient availability in Saccharomyces cerevisiae. Curr Genet. 2010;56:1-32.

24. Allen C, Buttner S, Aragon AD, Thomas JA, Meirelles O, Jaetao JE, et al. Isolation of quiescent and nonquiescent cells from yeast stationary-phase cultures. J Cell Biol. 2006;174:89-100.

25. Davidson GS, Joe RM, Roy S, Meirelles O, Allen CP, Wilson MR, et al. The proteomics of quiescent and nonquiescent cell differentiation in yeast stationary-phase cultures. Mol Biol Cell. 2011;22:988-98.

26. Aragon AD, Rodriguez AL, Meirelles O, Roy S, Davidson GS, Tapia PH, et al. Characterization of differentiated quiescent and nonquiescent cells in yeast stationary-phase cultures. Mol Biol Cell. 2008;19:1271-80.

27. Verduyn C, Postma E, Scheffers WA, Van Dijken JP. Effect of benzoic acid on metabolic fluxes in yeasts: a continuous-culture study on the regulation of respiration and alcoholic fermentation. Yeast. 1992;8:501-17.

28. Hahn-Hägerdal B, Karhumaa K, Larsson CU, Gorwa-Grauslund M, Görgens $J$, van Zyl WH. Role of cultivation media in the development of yeast strains for large scale industrial use. Microb Cell Fact. 2005;4:31.

29. Hanahan D. DNA Cloning, Volume 1. D. Glover, ed. edn: IRL Press, Ltd. London, 109.; 1985

30. Orij R, Postmus J, Ter Beek A, Brul S, Smits GJ. In vivo measurement of cytosolic and mitochondrial pH using a pH-sensitive GFP derivative in Saccharomyces cerevisiae reveals a relation between intracellular $\mathrm{pH}$ and growth. Microbiology. 2009;155:268-78.

31. Gietz RD, Schiestl RH. High-efficiency yeast transformation using the LiAc/SS carrier DNA/PEG method. Nat Protoc. 2007;2:31-4.

32. Parachin NS, Schelin J, Norling B, Radstrom P, Gorwa-Grauslund MF. Flotation as a tool for indirect DNA extraction from soil. Appl Microb Biotechnol. 2010;87:1927-33.

33. Zwietering $\mathrm{MH}$, Jongenburger I, Rombouts FM, van't Riet K. Modeling of the bacterial growth curve. Appl Environ Microbiol. 1990;56:1875-81.

34. Deere D, Shen J, Vesey G, Bell P, Bissinger P, Veal D. Flow cytometry and cell sorting for yeast viability assessment and cell selection. Yeast. 1998;14:147-60.

35. Landolfo S, Politi H, Angelozzi D, Mannazzu I. ROS accumulation and oxidative damage to cell structures in Saccharomyces cerevisiae wine strains during fermentation of high-sugar-containing medium. Biochim Biophys Acta. 2008;1780:892-8.

36. Gomes A, Fernandes E, Lima JL. Fluorescence probes used for detection of reactive oxygen species. J Biochem Bioph Meth. 2005;65:45-80.

37. Valkonen M, Mojzita D, Penttila M, Bencina M. Noninvasive high-throughput single-cell analysis of the intracellular $\mathrm{pH}$ of Saccharomyces cerevisiae by ratiometric flow cytometry. Appl Environ Microbiol. 2013;79:7179-87.

38. Swinnen S, Fernandez-Nino M, Gonzalez-Ramos D, van Maris AJ, Nevoigt $E$. The fraction of cells that resume growth after acetic acid addition is a strain-dependent parameter of acetic acid tolerance in Saccharomyces cerevisiae. FEMS Yeast Res. 2014;14:642-53.

39. Fernandez-Nino M, Marquina M, Swinnen S, Rodriguez-Porrata B, Nevoigt $\mathrm{E}$, Arino J. The cytosolic $\mathrm{pH}$ of individual Saccharomyces cerevisiae cells is a key factor in acetic acid tolerance. Appl Environ Microbiol. 2015;81:7813-21

40. van Dijken JP, Bauer J, Brambilla L, Duboc P, Francois JM, Gancedo $C$, et al. An interlaboratory comparison of physiological and genetic properties of four Saccharomyces cerevisiae strains. Enzyme Microb Tech. 2000;26:706-14.

41. Allen SA, Clark W, McCaffery JM, Cai Z, Lanctot A, Slininger PJ, et al. Furfural induces reactive oxygen species accumulation and cellular damage in Saccharomyces cerevisiae. Biotechnol Biofuels. 2010;3:2. 
42. Kim IS, Kim YS, Yoon HS. Glutathione reductase from Oryza sativa increases acquired tolerance to abiotic stresses in a genetically modified Saccharomyces cerevisiae strain. J Microbiol Biotechnol. 2012;22:1557-67.

43. Fitzgerald DJ, Stratford M, Narbad A. Analysis of the inhibition of food spoilage yeasts by vanillin. Int J Food Microbiol. 2003;86:113-22.

44. Palmqvist E, Grage H, Meinander NQ, Hahn-Hagerdal B. Main and interaction effects of acetic acid, furfural, and p-hydroxybenzoic acid on growth and ethanol productivity of yeasts. Biotechnol Bioeng. 1999;63:46-55.

45. Delvigne F, Zune Q, Lara AR, Al-Soud W, Sørensen SJ. Metabolic variability in bioprocessing: implications of microbial phenotypic heterogeneity. Trends Biotechnol. 2014:32:608-16.

46. Lencastre Fernandes R, Nierychlo M, Lundin L, Pedersen AE, Puentes Tellez PE, Dutta A, et al. Experimental methods and modeling techniques for description of cell population heterogeneity. Biotechnol Adv. 2011;29:575-99.

47. Stratford M, Steels H, Nebe-von-Caron G, Novodvorska M, Hayer K, Archer $D B$. Extreme resistance to weak-acid preservatives in the spoilage yeast Zygosaccharomyces bailii. Int J Food Microbiol. 2013;166:126-34.

48. Pampulha ME, Loureiro-Dias MC. Activity of glycolytic enzymes of Saccharomyces cerevisiae in the presence of acetic acid. Appl Microb Biotechnol. 1990;34:375-80.
49. Piper P, Calderon CO, Hatzixanthis K, Mollapour M. Weak acid adaptation: the stress response that confers yeasts with resistance to organic acid food preservatives. Microbiology. 2001;147:2635-42.

50. Neves AR, Pool WA, Kok J, Kuipers OP, Santos H. Overview on sugar metabolism and its control in Lactococcus lactis - the input from in vivo NMR. FEMS Microbiol Rev. 2005;29:531-54.

51. Drakulic T, Temple MD, Guido R, Jarolim S, Breitenbach M, Attfield PV, Dawes IW. Involvement of oxidative stress response genes in redox homeostasis, the level of reactive oxygen species, and ageing in Saccharomyces cerevisiae. FEMS Yeast Res. 2006;5:1215-28.

52. Grant CM. Role of the glutathione/glutaredoxin and thioredoxin systems in yeast growth and response to stress conditions. Mol Microbiol. 2001;39:533-41.

53. Ask M, Mapelli V, Hock H, Olsson L, Bettiga M. Engineering glutathione biosynthesis of Saccharomyces cerevisiae increases robustness to inhibitors in pretreated lignocellulosic materials. Microb Cell Fact. 2013;12:87.

54. Branduardi P, Fossati T, Sauer M, Pagani R, Mattanovich D, Porro D. Biosynthesis of vitamin $C$ by yeast leads to increased stress resistance. PLoS ONE. 2007;2:e1092

\section{Submit your next manuscript to BioMed Central and we will help you at every step:}

- We accept pre-submission inquiries

- Our selector tool helps you to find the most relevant journal

- We provide round the clock customer support

- Convenient online submission

- Thorough peer review

- Inclusion in PubMed and all major indexing services

- Maximum visibility for your research

Submit your manuscript at www.biomedcentral.com/submit 